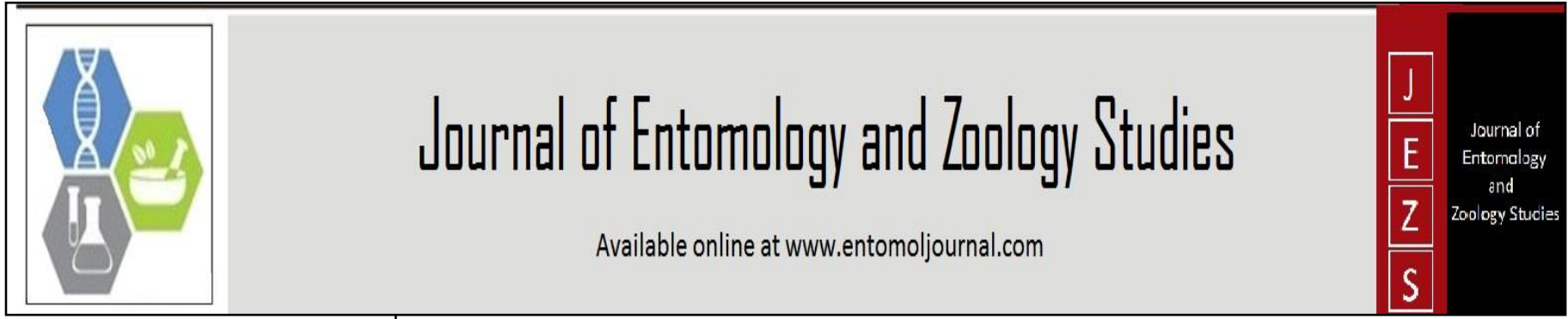

E-ISSN: 2320-7078

P-ISSN: 2349-6800

www.entomoljournal.com JEZS 2021; 9(1): 680-684 (C) 2021 JEZS

Received: 01-11-2020

Accepted: 03-12-2020

Senthilraja $\mathbf{N}$

Department of Entomology,

C.P. College of Agriculture,

Sardarkrushinagar Dantiwada

Agricultural University,

Sardarkrushinagar,

Banaskantha, Gujarat, India

PS Patel

Department of Entomology

C.P. College of Agriculture,

Sardarkrushinagar Dantiwada

Agricultural University,

Sardarkrushinagar,

Banaskantha, Gujarat, India

Corresponding Author:

Senthilraja $\mathbf{N}$

Department of Entomology,

C.P. College of Agriculture,

Sardarkrushinagar Dantiwada

Agricultural University,

Sardarkrushinagar,

Banaskantha, Gujarat, India

\section{Screening of cowpea varieties/genotypes against the pulse beetle, Callosobruchus maculatus (F.)}

\author{
Senthilraja $\mathbf{N}$ and PS Patel
}

DOI: https://doi.org/10.22271/j.ento.2021.v9.i1j.8223

\section{Abstract}

The performance of 14 cowpea varieties/genotypes against Callosobruchus maculatus was assessed under the no-choice artificial infestation condition and significant variations were observed. GC 3 was least preferred for egg laying. Significantly less growth index was recorded in GC 4 followed by GC 5 . Based on per cent infestation, the varieties/genotypes GC 6, GC 1501 and GC 1601 were classified as highly susceptible and GC 4, GC 5, GC 1304 and GC 1702 as the least susceptible. The weight loss due to feeding by $C$. maculatus ranged from 5.38 to 15.95 per cent. Growth index had highly significant negative relationship with mean development period and highly significant positive relationship with adult emergence. Adult emergence had a highly significant negative relationship with development period and positive relationship with weight loss. Number of eggs laid by $C$. maculatus had a negative non significant relationship with adult emergence.

Keywords: Callosobruchus maculatus, cowpea, chrysomelidae, screening

\section{Introduction}

Pulses are the main source of protein for the large vegetarian population of India. It is a longestablished fact that, pulses are an important part of the daily diet, particularly in Asian continent. Among the pulses, cowpea [Vigna unguiculata (L.) Walp.] is a premier crop cultivated across all the parts of the country and it belongs to the family Fabaceae. It originated in West Africa. It is commonly known as black eyed bean in the world. Though, cowpea is emerging as one of the most important food legumes to tackle malnutrition as it is rich in protein and vitamins, but the yield of cowpea is affected by various biotic factors and abiotic factors both in the field and storage conditions. Among the various pests of cowpea, the pulse beetle, Callosobruchus Spp. is an important pest of stored cowpea causing considerable losses to cowpea ${ }^{[1]}$. Pulse beetle belongs to the order Coleoptera, family Chrysomelidae and the subfamily Bruchinae. It is commonly known as cowpea weevil and bean beetle. The number of economically important species that attack stored pulses throughout the world are included in the genus Callosobruchus. But, C. maculatus (F.), C. chinensis (L.) and C. analis (F.) are the important species in India. When compared to other grain legume hosts, cowpea is an excellent host for $C$. maculatus ${ }^{[2]}$. Generally, pulse beetle infestation starts from the field, where the adult females oviposit on the mature pods before harvesting. After hatching, the grubs penetrate into the pods and remain as hidden infestation as they are concealed within the developing seeds. To overcome this problem, farmers are using different synthetic insecticides, but they have toxic effects on the environment and non target organisms. Hence, the use of resistant varieties/genotypes is considered as the most promising ways to reduce dependence on pesticides in agriculture. Considerable amount of work on relative susceptibility of different pulse varieties/genotypes against the pulse beetle has been done in India. But practically, no information is available on the susceptibility of different cowpea genotypes to the pulse beetle. Hence, the outcome of this study will be very useful for the identification of the resistant cultivars of cowpea.

\section{Materials and Methods}

The screening studies were conducted at Department of Entomology, C. P. College of Agriculture, S. D. Agricultural University, Sardarkrushinagar during 2019-20. For the evaluation of different cowpea varieties/genotypes against the pulse beetle, fourteen cowpea 
varieties/genotypes viz., GC 3, GC 4, GC 5, GC 6, GC 1304, GC 1501, GC 1506, GC 1601, GC 1602, GC 1603, GC 1612, GC 1701, GC 1702 and GC 1710 were obtained from the Pulses Research Station of S. D. Agricultural University. Infestation free, sound and healthy cowpea seeds of each variety/genotype were shade dried for three days to attain the uniformity in moisture content $(9 \%)$ of different genotypes of cowpea.

\subsection{Rearing of pulse beetle in the laboratory}

Cowpea seeds infested with pulse beetle were collected from the Pulses Research Station, S. D. Agricultural University, Sardarkrushinagar and the same were multiplied by releasing five pairs of adult beetles into plastic jars containing $200 \mathrm{~g}$ of disinfested cowpea seeds. Twelve of such jars were maintained for mass culturing of the pulse beetle. The jars were kept undisturbed under laboratory condition and mass cultured for 2-3 generations and the freshly emerged adults were used for the experimental studies.

\subsection{No-choice test}

Relative susceptibility of cowpea varieties/genotypes against the pulse beetle was studied under no choice test ${ }^{[3]}$. For this, 100 numbers weighed seeds of fourteen varieties/genotypes were kept separately in $100 \mathrm{ml}$ plastic container and two pairs of one to two days old adults ( 2 males and 2 females) of the pulse beetle were released in each container separately. The mouth of the containers was covered with muslin cloth fastened with a rubber band. The released insects were removed after 72 hours with the expectation of maximum oviposition during this period and number of eggs laid on the surface of the seeds of each variety/genotype was recorded. The experiment was continued for 30 more days to observe the adult emergence. The following parameters were used to determine the development of the pulse beetle in different varieties/genotypes.

\subsubsection{Adult emergence (\%)}

Observations for emergence was recorded at a regular interval of $24 \mathrm{hrs}$. The adult emergence was calculated using the following standard formula suggested by Sharma and Thakur $(2014)^{[4]}$.

$$
\text { Adult emergence }(\%)=\frac{\text { Number of adults emerged }}{\text { Number of eggs laid }} \times 100
$$

\subsubsection{Developmental period (days)}

The time taken from oviposition to adult emergence was taken as a developmental period ${ }^{[4]}$.

\subsubsection{Growth Index (GI)}

The suitability of the varieties/genotypes for the development of bruchid is determined on the basis of growth index ${ }^{[4]}$. Varieties/genotypes with a high growth index are considered as susceptible and those with a low growth index are considered as resistant. This is based on the assumption that progeny development would take a longer time in a resistant than in a susceptible genotype. The Growth Index (GI) was calculated by dividing the percentage adult emergence by the developmental period.

$$
\text { Growth Index }=\frac{\text { Adult emergence }(\%)}{\text { Developmental period (days) }}
$$

\subsubsection{Weight loss $(\%)$}

After removing the pulse beetles, the final weight was taken with a single pan electric balance separately for each treatment. The per cent loss in weight was calculated by following formula suggested by Sharma and Thakur (2014) ${ }^{[4]}$.

$$
\text { Weight loss }(\%)=\frac{\text { Initial weight of seeds }(\mathrm{g})-\text { Final weight of seeds }(\mathrm{g})}{\text { Initial weight of seeds }(\mathrm{g})} \times 100
$$

\subsubsection{Per cent infestation}

The per cent infestation can be calculated with the help of following standard formula and they were categorised according to Deshpande et al. (2011) ${ }^{[5]}$.

Per cent infestation $=\frac{\text { No. of seeds with emergent holes }}{\text { Total number of seeds observed }} \times 100$

Table 1: Classification of cowpea varieties/genotypes based on per cent seed infestation by pulse beetle

\begin{tabular}{|c|c|c|}
\hline S. No & Class & Per cent infestation \\
\hline 1 & Highly resistant & $0-20$ \\
\hline 2 & Moderately resistant & $21-40$ \\
\hline 3 & Least susceptible & $41-60$ \\
\hline 4 & Moderately susceptible & $61-80$ \\
\hline 5 & Highly susceptible & $81-100$ \\
\hline
\end{tabular}

\section{Results and Discussions}

The results revealed that twelve cowpea varieties/genotypes screened under no-choice laboratory conditions displayed significant variation in the expression of resistance to $C$. maculatus. There were significant differences between the genotypes in terms of number of eggs laid, adult emergence, seed weight loss, mean development period and growth index of $C$. maculatus on cowpea under no choice conditions.

\subsection{Number of eggs laid/100 seeds}

The number of eggs laid in no-choice condition by two pairs of beetles in 100 seeds of cowpea varieties/genotypes varied significantly from 59.67 in GC 1702 to 119.00 eggs in GC 6 . The data are presented in Table 2. Significantly less oviposition was noticed in GC 1702 (59.67 eggs/100 seeds) followed by GC 3 (83.00 eggs/100 seeds), GC 1304 (90.67 eggs/100 seeds) and GC 5 (91.00 eggs/100 seeds). The variety GC 6 was more preferred by $C$. maculatus in no-choice condition than the rest of the cowpea varieties/genotypes. Decrease in oviposition by $C$. maculatus is associated with seed physical characters such as colour, texture, size and hardness, which increase the resistance of cowpea varieties/genotypes [6]. On a similar experiment, Sharma and Thakur (2014) ${ }^{[4]}$ also noticed that the seeds with smooth surfaces were preferred more for egg laying by pulse beetle over the rough seed surface. GC 1702 and GC 3 have wrinkled and rough seed coat texture respectively. Similarly, Castro et al. (2013) found lower oviposition in variety/genotype IT85 F-2687, which was the only one among the fifty tested cowpea varieties/genotypes with a rough seed coat.

\subsection{Adult emergence (\%)}

It is clear from the Table 2 that the per cent adult emergence of $C$. maculatus on different cowpea varieties/genotypes showed significant differences and ranged from 57.72 to 82.7 per cent. The minimum adult emergence was recorded in GC 4 followed by GC 1701 and GC 1602 . The maximum adult 
emergence was recorded in GC 1601, which was the most susceptible among the fourteen varieties/genotypes followed by GC 1702 and GC 3. The less oviposition in the varieties/genotypes GC 1601, GC 3 and GC 1702 may reduce the intraspecific competition among the $C$. maculatus larvae. This might be the reason for the maximum adult emergence in these varieties/genotypes. The resistance of those varieties/genotypes with low adult emergence has been related to varying sorts of the reserve protein and vicilin, which can't be metabolized by the insect's midgut proteinases, limiting the larvae's food supply and interfering with the development of C. maculatus ${ }^{[8]}$.

Table 2: Impact of different cowpea varieties/genotypes on the various growth parameters of $C$. maculatus

\begin{tabular}{|c|c|c|c|c|c|c|c|}
\hline $\begin{array}{l}\text { S. } \\
\text { No. }\end{array}$ & $\begin{array}{l}\text { Genotype/ } \\
\text { Variety }\end{array}$ & $\begin{array}{c}\text { No. of } \\
\text { eggs } / 100 \text { seeds }\end{array}$ & $\begin{array}{c}\text { Adult } \\
\text { Emergence (\%) }\end{array}$ & $\begin{array}{l}\text { Developmental } \\
\text { Period (days) }\end{array}$ & Growth Index & Per cent Infestation & $\begin{array}{c}\text { Weight Loss } \\
(\%)\end{array}$ \\
\hline 1 & GC 3 & 83.00 & $64.92(81.57)$ & 20.67 & 3.95 & $52.23(62.02)$ & $23.14(14.96)$ \\
\hline 2 & GC 4 & 101.33 & $49.71(57.72)$ & 20.00 & 2.89 & $49.37(57.12)$ & $16.29(7.37)$ \\
\hline 3 & GC 5 & 91.00 & $55.79(67.88)$ & 21.67 & 3.08 & $49.70(57.70)$ & $16.55(7.61)$ \\
\hline 4 & GC 6 & 119.00 & $56.22(68.61)$ & 21.00 & 3.26 & $64.39(80.84)$ & $24.92(15.95)$ \\
\hline 5 & GC 1304 & 90.67 & $54.50(65.82)$ & 21.33 & 3.08 & $49.49(57.34)$ & $21.89(13.41)$ \\
\hline 6 & GC 1501 & 106.33 & $62.49(78.19)$ & 21.00 & 3.71 & $64.04(80.37)$ & $21.95(12.29)$ \\
\hline 7 & GC 1506 & 105.33 & $57.24(70.26)$ & 22.67 & 3.10 & $58.58(72.36)$ & $17.11(8.16)$ \\
\hline 8 & GC 1601 & 104.00 & $65.85(82.77)$ & 21.00 & 3.91 & $66.50(83.61)$ & $21.42(12.85)$ \\
\hline 9 & GC 1602 & 99.33 & $54.12(65.18)$ & 21.00 & 3.10 & $53.22(63.69)$ & $22.38(14.00)$ \\
\hline 10 & GC 1603 & 94.00 & $60.71(75.60)$ & 21.00 & 3.60 & $56.88(69.68)$ & $15.47(6.62)$ \\
\hline 11 & GC 1612 & 93.00 & $54.41(65.66)$ & 21.00 & 3.12 & $51.64(61.02)$ & $15.82(6.94)$ \\
\hline 12 & GC 1701 & 108.33 & $53.54(64.22)$ & 20.33 & 3.15 & $56.88(69.67)$ & $20.14(11.36)$ \\
\hline 13 & GC 1702 & 59.67 & $64.71(81.28)$ & 20.67 & 3.93 & $43.93(47.66)$ & $13.03(5.38)$ \\
\hline 14 & GC 1710 & 111.33 & $55.96(66.57)$ & 19.67 & 3.39 & $60.32(75.02)$ & $20.27(11.51)$ \\
\hline \multirow{3}{*}{\multicolumn{2}{|c|}{$\begin{array}{l}\text { S. Em. } \pm \\
\text { C. D. at } 5 \% \\
\text { C. V. } \%\end{array}$}} & 5.45 & 2.59 & 0.36 & 0.19 & 1.86 & 0.76 \\
\hline & & 15.79 & 7.51 & 1.03 & 0.53 & 5.34 & 2.20 \\
\hline & & 9.68 & 7.77 & 2.95 & 9.49 & 5.79 & 6.82 \\
\hline
\end{tabular}

Figures in parentheses are retransformed values, those outside are Arc sin transformed values.

\subsection{Developmental period (days)}

The perusal of the data in Table 2 shows that the mean developmental period of $C$. maculatus on different cowpea varieties/genotypes significantly differed from each other. It ranged from 19.67 to 22.67 days. The highest developmental period was 22.67 days noticed in GC 1506 followed by GC 5 (21.67 days), GC 1304 (21.33 days). The five varieties/genotypes viz., GC 6, GC 1501, GC 1601, GC 1602, GC 1603 and GC 1612 had the same developmental period of 21 days. The least developmental period was noticed in GC 1710 (19.67 days). It was followed by GC 4 (20.00 days), GC 1701 (20.33 days), GC 3 (20.67 days) and GC 1702 (20.67 days). Sharma and Thakur (2014) ${ }^{[4]}$ also found the developmental period of $C$. maculatus on different cowpea genotypes /varieties in the range of $19.0 \pm 1.15$ to $24.0 \pm 1.82$ days.

Usually the varieties/genotypes with more developmental period are considered as least susceptible. The variation in the development time of the beetle could be, therefore, be the result of intra-specific competition of larvae developing within seeds and depending on the population of the larvae, longer or shorter among the different beetle populations. High larval competition may prolong the development of the beetle ${ }^{[9]}$. According to Smith and Clement (2012) ${ }^{[10]}$, the antibiosis type of resistance is characterized by an increased span of time between the egg and adult phases, as well as by the reduction in adult emergence. And also, they clarified that the ability of a resistant host to delay the development of pests results in decreased reproduction rates or the number of insects in natural populations due to the increased average time of each generation. The results are in close proximity to Tripathi et al. (2015) [11], who also reported that the development period was significantly longer in resistant varieties of cowpea than the susceptible varieties. Further, they also noted that the developmental period was prolonged by 8 to 10 days on the least preferred cowpea varieties.

\subsection{Growth Index}

Suitability of cowpea varieties/genotypes for development of C. maculatus was determined on the basis of growth index. It was based on the idea that few offspring would emerge out of a resistant variety/genotype and progeny development would take a longer time in a resistant than in a susceptible variety/genotype ${ }^{[11]}$. Varieties/genotypes with a low growth index were considered as resistant and those with a high growth index were considered as susceptible. The growth index of cowpea varieties/genotypes ranged from 2.89 to 3.95 (Table 2). Significantly less growth index was recorded in GC 4 followed by GC 5 and GC 1304. Significantly highest growth index was recorded in GC 3 followed by GC 1702 and GC 1601. These varieties/genotypes are more suitable for the development of the pulse beetle. The variety GC 3 having the highest growth index was least preferred by the C. maculatus for egg laying in no-choice condition. These results showed that the preference of the pulse beetle for oviposition did not have any relationship with the development of the beetle. Singh and Sharma (2003) ${ }^{[12]}$ also noticed that pulse beetle preferred all the varieties for egg laying, while differences in growth index were observed on different varieties.

\subsection{Per cent infestation}

Among different varieties/genotypes, per cent infestation by C. maculatus varied from 47.66 to 83.61 per cent (Table 2). Significantly less damage was recorded in GC 1702 followed by GC 4, GC 1304 and GC 5. Significantly the highest per cent infestation was found in GC 1601. Based on per cent infestation, the fourteen cowpea varieties/genotypes can be classified as highly susceptible (GC 6, GC 1501 and GC 1601), moderately susceptible (GC 3, GC 1506, GC 1602, GC 1603, GC 1612, GC 1701 and GC 1710) and the least susceptible (GC 4, GC 5, GC 1304 and GC 1702).

This classification was based on the earlier classification 
reported by ${ }^{[14]}$. The present results were in conformity with Deshpande et al. (2011) ${ }^{[5]}$ and Augustine et al. (2018) [13] who also reported that none of the cowpea varieties/genotypes were completely resistant to the attack of beetle, although they differed in their susceptibilities. The variation in susceptibility of the varieties/genotypes can be attributed to the association between some physiochemical characteristics of the seeds.

Table 3: Classification of varieties/genotypes based on per cent infestation

\begin{tabular}{|c|c|c|c|c|}
\hline S. No & Class & Per cent infestation & Number of genotype/variety & Genotype/variety \\
\hline 1 & Highly resistant & $0-20$ & 0 & - \\
\hline 2 & Moderately resistant & $21-40$ & 0 & - \\
\hline 3 & Least susceptible & $41-60$ & 4 & GC 4, GC 5, GC 1304 and GC 1702 \\
\hline 4 & Moderately susceptible & $61-80$ & 7 & $\begin{array}{c}\text { GC 3, GC 1506, GC 1602, GC 1603, } \\
\text { GC 1612, GC 1701 and GC 1710 }\end{array}$ \\
\hline 5 & Highly susceptible & $81-100$ & 3 & GC 6, GC 1501 and GC 1601 \\
\hline
\end{tabular}

\subsection{Weight loss (\%)}

The $C$. maculatus larvae feed on the internal contents of the cowpea seeds, which leads to weight loss. The data presented in Table 2 implicate that the weight loss ranged from 5.38 to 15.95 per cent. Significantly less weight loss was recorded in GC 1702 (5.38 \%), which was on par with GC 1603 (6.62 \%) and GC 1612 (6.94 \%). According to Deshpande et al. (2011) [5], the variation in seed weight loss by $C$. maculatus was mainly due to variation in per cent infestation level, adult emergence and also the inherent capacity of each genotypic response.

\subsection{Relationship between growth index of $C$. maculatus and various susceptibility parameters}

Correlation analysis between growth index and various growth parameters of $C$. maculatus in different cowpea varieties/genotypes (Table 4) revealed that growth index had highly significant negative relationship with mean development period $(\mathrm{r}=-0.504 * *)$, highly significant positive relationship with adult emergence $(\mathrm{r}=0.766 * *)$ and non significant negative relationship with number of eggs laid $(\mathrm{r}=$ - 0.166) and non significant positive relationship with per cent infestation $(r=0.169)$ and weight $\operatorname{loss}(r=0.118)$. The findings of the present investigation perfectly coincide with the findings of Tripathi et al. (2015) [11], who found a significant negative relationship of growth index with mean development period and significant positive relationship of growth index as well as weight loss with adult emergence. Miesho et al. (2018) ${ }^{[14]}$ noticed that the growth index had a significant negative correlation with the insect development period and a significant positive relation to the number of holes and weight loss.

Adult emergence had a highly significant negative relationship with development period $\left(\mathrm{r}=-0.426^{* *}\right)$ and positive relationship with per cent infestation $(\mathrm{r}=0.060)$ and weight loss $(r=0.147)$. Appleby and Credland $(2004)^{[15]}$ also noticed that the effect of the resistant seeds delayed development, which resulted in an extended adult emergence period and increased the postembryonic mortality.

Number of eggs laid by $C$. maculatus had a negative relationship with growth index $(\mathrm{r}=0.166)$ and all the growth parameters viz., development period $(\mathrm{r}=-0.089)$, adult emergence $(r=-0.171)$, per cent infestation $(r=-0.049)$ and weight loss $(r=-0.115)$. Weight loss had highly significant positive relationship with per cent infestation $\left(\mathrm{r}=0.481^{* *}\right)$ and developmental period $\left(\mathrm{r}=0.405^{* *}\right)$. This shows that when the developmental period increases the weight loss is also increasing. The findings are in close conformity with Miesho et al. (2018) ${ }^{[14]}$, who found a significant negative relation of the number of eggs with the developmental period of pulse beetle. This may be due to the intraspecific competition due to the greater number of eggs laid which drastically reduced the adult emergence, per cent infestation and weight loss.

The identification of various factors which are responsible for the reduction in pulse beetle infestation is recommended to know the causes for the differences in relative susceptibility among the cowpea varieties/genotypes.

Table 4: Correlation matrix of growth index and various growth parameters of $C$. maculatus on cowpea varieties/genotypes

\begin{tabular}{|c|c|c|c|c|c|c|}
\hline Parameters & GI & Developmental period & Adult emergence & No. of eggs & Per cent infestation & Weight loss \\
\hline GI & - & $-0.504^{* *}$ & $0.766^{* *}$ & -0.166 & 0.169 & 0.118 \\
\hline Developmental Period & & - & $-0.426^{* *}$ & -0.089 & $0.707^{* *}$ & $0.405^{* *}$ \\
\hline Adult Emergence & & & - & -0.171 & 0.060 & 0.147 \\
\hline No of eggs & & & & - & -0.049 & -0.115 \\
\hline Per cent infestation & & & & & - & $0.481^{* *}$ \\
\hline Weight loss & & & & & - \\
\hline$*$ Highly significant at 1 per cent level, 'r' $(0.01)>2.704$ Significant N=42
\end{tabular}

\subsection{Ranking of cowpea varieties/genotypes in order of relative susceptibility to $C$. maculatus}

The fourteen cowpea varieties/genotypes were ranked in order of their relative susceptibilities using the parameters such as oviposition, adult emergence, developmental period, growth index, per cent infestation and weight loss were indicated in the Table 5 and the descending order of their relative resistance to the $C$. maculatus was GC $1304>\mathrm{GC} 5>\mathrm{GC} 4>$ GC $1702>$ GC $1612>$ GC $1506>$ GC $1602>$ GC $1603>$ GC $1701>$ GC $3>$ GC $1601>$ GC $6>$ GC $1501>$ GC 1710 .

The varieties/genotypes, which recorded less growth index like GC 4 (2.89), GC 5 (3.08) and GC 1304 (3.08) were still found to be the least preferred, while the varieties/genotypes having the highest growth index like GC 3, GC 1601 and GC 1501 were highly susceptible to bruchid infestation.

The variety GC 3 , which scored the best in the reducing the number of eggs laid by $C$. maculatus, but it failed to reduce the development of the pulse beetle, as this variety/genotype had not scored well in the growth index, adult emergence percentage and weight loss per cent.

Similar findings were reported by Badii et al. (2013) ${ }^{[16]}$, who ranked 22 cowpea varieties/genotypes in order of their 
relative susceptibilities using parameters such as oviposition, adult emergence, seed weight loss and growth index. The variation in different parameters may be due to genetic factors or possible presence of bio chemical content of seeds such as total protein, free amino acid, total soluble sugars, phenols, tannins and flavonoids.

Table 5: Ranking of cowpea varieties/genotypes in order of relative susceptibility to $C$. maculatus

\begin{tabular}{|c|c|c|c|c|c|c|c|c|c|c|}
\hline $\begin{array}{l}\text { Sr. } \\
\text { No. }\end{array}$ & $\begin{array}{l}\text { Genotype/ } \\
\text { Variety }\end{array}$ & $\begin{array}{l}\text { Eggs/25 g } \\
\text { seeds (Free } \\
\text { choice) }\end{array}$ & $\begin{array}{c}\text { Eggs/100 } \\
\text { seeds (No- } \\
\text { choice) }\end{array}$ & $\begin{array}{c}\text { Adult } \\
\text { Emergence } \\
(\%)\end{array}$ & $\begin{array}{l}\text { Developmental } \\
\text { Period (days) }\end{array}$ & $\begin{array}{l}\text { Growth } \\
\text { index }\end{array}$ & $\begin{array}{c}\text { Per cent } \\
\text { infestation } \\
(\%)\end{array}$ & $\begin{array}{c}\text { Weight } \\
\text { loss } \\
(\%)\end{array}$ & $\begin{array}{l}\text { Total } \\
\text { ranks }\end{array}$ & $\begin{array}{l}\text { Mean } \\
\text { ranks }\end{array}$ \\
\hline 1 & GC 3 & 1 & 2 & 13 & 10 & 14 & 6 & 13 & 59 & 8.43 \\
\hline 2 & GC 4 & 6 & 8 & 1 & 13 & 1 & 2 & 4 & 35 & 5.00 \\
\hline 3 & GC 5 & 9 & 4 & 7 & 2 & 2 & 4 & 5 & 33 & 4.71 \\
\hline 4 & GC 6 & 7 & 14 & 8 & 4 & 8 & 13 & 14 & 68 & 9.71 \\
\hline 5 & GC 1304 & 5 & 3 & 5 & 3 & 3 & 3 & 11 & 33 & 4.71 \\
\hline 6 & GC 1501 & 12 & 11 & 11 & 4 & 11 & 12 & 9 & 70 & 10.00 \\
\hline 7 & GC 1506 & 8 & 10 & 9 & 1 & 4 & 10 & 6 & 48 & 6.86 \\
\hline 8 & GC 1601 & 3 & 9 & 14 & 4 & 12 & 14 & 10 & 66 & 9.43 \\
\hline 9 & GC 1602 & 11 & 7 & 3 & 4 & 5 & 7 & 12 & 49 & 7.00 \\
\hline 10 & GC 1603 & 10 & 6 & 10 & 4 & 10 & 8 & 2 & 50 & 7.14 \\
\hline 11 & GC 1612 & 14 & 5 & 4 & 4 & 6 & 5 & 3 & 41 & 5.86 \\
\hline 12 & GC 1701 & 4 & 12 & 2 & 12 & 7 & 8 & 7 & 52 & 7.43 \\
\hline 13 & GC 1702 & 2 & 1 & 12 & 10 & 13 & 1 & 1 & 40 & 5.71 \\
\hline 14 & GC 1710 & 13 & 13 & 6 & 14 & 9 & 11 & 8 & 74 & 10.57 \\
\hline
\end{tabular}

Infestation and damage: 1 = least susceptible/infested, $14=$ most susceptible/infested

Total ranks $=$ Sum of the ranks of varieties/genotypes for all growth parameters

Mean ranks $=$ Sum of the ranks/Total number of parameters

\section{Conclusion}

The overall performance of the varieties/genotypes GC 1304, GC 5, GC 4, GC 1702 and GC 1612 was the best and these varieties could be explored for the presence of genetic and bio chemical parameters, which made these varieties/genotypes the least susceptible than the others.

\section{References}

1. Adam JI, Baidoo PK. Susceptibility of five cowpea (Vigna unguiculata) varieties to attack by Callosobruchus maculatus (Fab.) (Coleoptera: Bruchidae). Journal of the Ghana Science Association. 2008;10(2):85-92.

2. Messina FJ, Lish AM, Gompert Z. Variable responses to novel hosts by populations of the seed beetle Callosobruchus maculatus (Coleoptera: Chrysomelidae: Bruchinae). Environmental Entomology. 2018;47:11941202.

3. Giga DP, Smith RH. Varietal resistance and intra-specific competition in the cowpea weevils Callosobruchus maculatus and C. chinensis (Coleoptera: Bruchidae). Journal of Applied Ecology 1981;18:755-776.

4. Sharma S, Thakur DR. Comparative developmental compatibility of Callosobruchus maculatus on cowpea, chickpea and soybean genotypes. Asian Journal of Biological Sciences 2014;7(6):270-276.

5. Deshpande VK, Makanur B, Deshpande SK, Adiger S, Salimath PM. Quantitative and qualitative losses caused by Callosobruchus maculates in cowpea during seed storage. Plant Archives 2011;11:723-731.

6. Gbaye O, Holloway G. Varietal effects of cowpea, Vigna unguiculata, on tolerance to malathionin Callosobruchus maculatus (Coleoptera: Bruchidae). Journal of Stored Products Research 2011;47:365-371.

7. Castro MDJP, Baldin ELL, Cruz PL, Souza CM, Silva PHS. Characterization of cowpea genotype resistance to Callosobruchus maculatus. Pesquisa Agropecuaria Brasileira 2013;48(9):1201-1209.

8. Domingues SJS, Melo FR, Aguiar JM, Affonso AG,
Giuli JSA, Rose JL et al. Resistance of Vigna unguiculata (cowpea) seeds to Callosobruchus maculatus is restricted to cotyledonary tissues. Journal of the Science of Food and Agriculture 2006;86:1977-1985.

9. Audi AH, Ayertey JN, Kyerematen R. Relative susceptibility of different cowpea varieties to attack by the cowpea beetle, Callosobruchus maculatus (F). Savannah Journal of Agriculture 2011;6(2):53-61.

10. Smith CM, Clement SL. Molecular bases of plant resistance to arthropods. Annual Review of Entomology 2012;57:309-328.

11. Tripathi K, Chauhan SK, Gore PG, Prasad TV, Kalyani S, Bhalla S. Screening of cowpea [Vigna unguiculata (L.) Walp.] accessions against pulse beetle, Callosobruchus chinensis (L.). Legume Research 2015;38(5):675-680.

12. Singh S, Sharma G. Preference of Callosobruchus chinensis in pea varieties. Indian Journal of Entomology. 2003;65:277-280.

13. Augustine N, Balikai RA, Deshpande SK. Varietal screening and bio chemical basis of resistance in cowpea against pulse beetle, Callosobruchus chinensis (L.) in storage. Journal of Experimental Zoology India 2018;21(2):1151-1154.

14. Miesho WB, Gebremedhin HM, Msiska UM, Mohammed KE, Malinga GM, Sadik K et al. New sources of cowpea genotype resistance to cowpea bruchid Callosobruchus maculatus (F.) in Uganda. International Journal of Agronomy and Agricultural Research 2018;12(4):39-52.

15. Appleby $\mathrm{JH}$, Credland PF. Variation in responses to susceptible and resistant cowpeas among West African populations of Callosobruchus maculatus (Coleoptera: Bruchidae). Journal of Economic Entomology 2004;96:489-502.

16. Badii KB, Asante SK, Sowley ENK. Varietal susceptibility of cowpea (Vigna unguiculata L.) to the storage beetle, Callosobruchus maculatus F. (Coleoptera: Bruchidae). International Journal of Scientific \& Technology Research 2013;2(4):82-89. 